\title{
Unusual Membranous Structures in Cytochrome $a$-deficient Mutants of Bacillus subtilis
}

\author{
By ELISABETH B. FREESE \\ Laboratory of Molecular Biology, National Institute of Neurological Diseases \\ and Stroke, National Institutes of Health, Public Health Service, \\ U.S. Department of Health, Education and Welfare, \\ Bethesda, Maryland, 20014, U.S.A.
}

(Received 29 August 1972; revised 7 November 1972)

\section{SUMMARY}

In cytochrome $a$-deficient mutants of Bacillus subtilis, which grow to a reduced extinction of $600 \mathrm{~nm}$ and cannot sporulate, exceptionally large membranous structures (mesosomes) were observed with the electron microscope. They appeared not only at the sites of septation but also attached to unfinished, unseparated cross-walls of cell division and prespore septa. The parental strain grew and sporulated normally and did not show any unusual membranous structures.

\section{INTRODUCTION}

Electron micrographic studies of the fine structure of bacteria combined with results from cytochemical reactions and enzyme studies indicate that membranous structures, called mesosomes, are the sites of membrane and cross-wall synthesis (Chapman \& Hillier, I 953; Fitz-James, 1960; Ellar, Lundgren \& Slepecky, I967; Fitz-James \& Young, 1969), have lysosomal functions (Reusch \& Berger, 1972), and facilitate the separation of bacterial chromosomes (Ryter \& Jacob, 1963). In addition to their functions in cell division, mesosomes are also found at the sites of prespore septation (Ellar et al. 1967; Fitz-James, 1960). Since cytochromes are located in the bacterial membrane (van der Winkel \& Murray, I962; van Iterson, 1965; Reaveley \& Rogers, I969) and, since the electron transport system is involved in the re-oxidation of coenzymes, the transport of many substrates, and the regeneration of ATP, it seemed interesting to investigate the development of mesosomes in mutants of Bacillus subtilis that are known to lack cytochrome $a$. These mutants can grow only to a low extinction (at $600 \mathrm{~nm}$ ) and they cannot sporulate (H. Taber and Taber \& Freese, in preparation). This paper shows that the mesosomes of such mutants develop into huge membrane structures which are unable to support normal septation.

\section{METHODS}

The cytochrome a-deficient mutants of Bacillus subtilis were obtained from Dr H. Taber. They were derived from strain $60317\left(\mathrm{trp}^{-}\right.$, ile $\left.^{-}\right)$.

Cells were grown in nutrient sporulation medium (NSMP) (Fortnagel \& Freese, 1968) plus $25 \mu \mathrm{g} / \mathrm{ml}$ tryptophan + isoleucine. Bacterial growth was measured spectrophotometrically at wave length $600 \mathrm{~nm}\left(E_{600}=\right.$ absorbancy at $\left.600 \mathrm{~nm}\right)$. To measure formation of heatresistant spores, samples were taken, heated at $75^{\circ} \mathrm{C}$ for $\mathrm{I} 5 \mathrm{~min}$, and plated on Tryptose Blood Agar Base (TBAB) (Difco, Detroit, Michigan, U.S.A.) plates. 


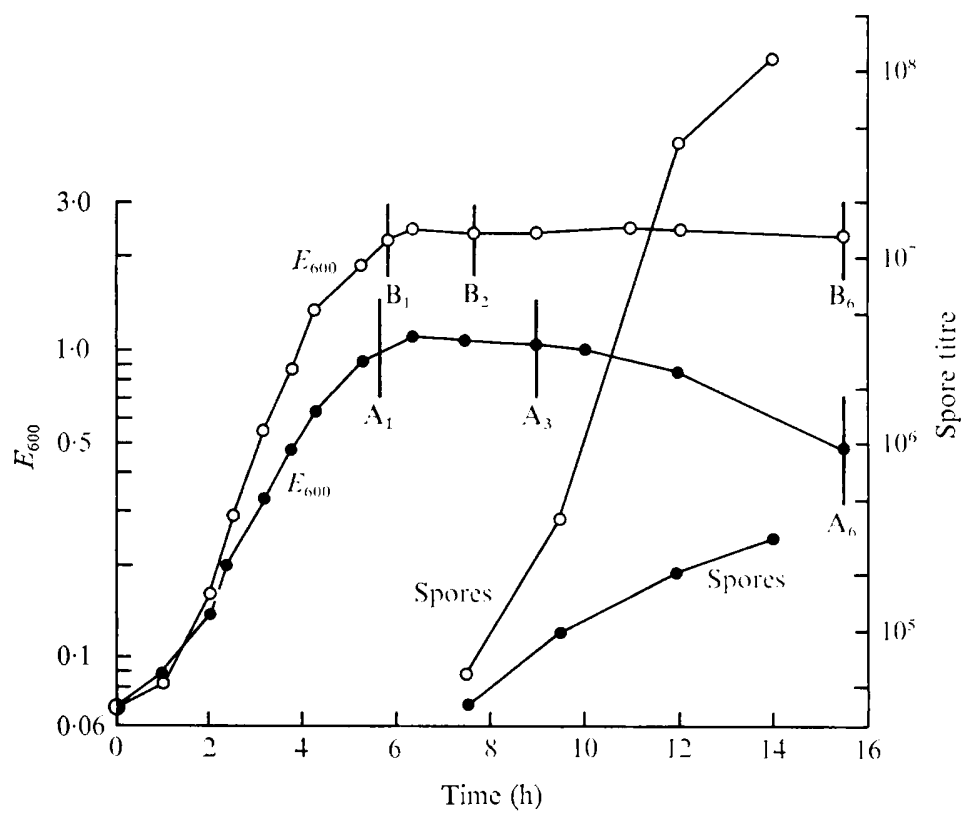

Fig. I. Growth of Bacillus subtilis strains in NSMP + trp + ile. $\odot$, Parent strain 60317 , with normal cytochromes; mutant 60843 , deficient in cytochrome $a . \mathrm{A}_{1}, \mathrm{~A}_{3}, \mathrm{~A}_{6}$, and $\mathrm{B}_{1}, \mathrm{~B}_{2}, \mathrm{~B}_{6}$ indicate the times at which samples were taken for studies with the electron microscope.

For electron microscopy: samples were taken after different times of growth, fixed in glutaraldehyde, osmium, stained in uranyl, embedded in Epon, sectioned with a Reichert microtome, and stained again with lead citrate as described earlier (Freese, Cole, Klofat \& Freese, 1970). Pictures were taken with a Zeiss electron microscope EM 9A.

\section{RESULTS}

The three cytochrome $a$-deficient mutants investigated grow only to a low $E_{600}$ in NSMP and are oligosporogenic. Strain 60843 is deficient in cytochrome $a$ but has normal amounts of cytochromes $b$ and $c$. As can be seen in Fig. I, the mutant grew more slowly in NSMP and attained a lower maximum $E_{600}$ than the parental strain (60317). While the parental strain sporulated normally, mutant 60843 sporulated poorly. Samples for fine structure analysis were taken at different times up to $10 \mathrm{~h}$ after growth had stopped.

In contrast to the parental strain, mutant 60843 developed abnormal structures. At the time of sample $\mathrm{A}_{3}$ (Fig. 1), many cells contained unusually large membranous structures (mesosomes) connected to the cross-wall (Fig. 2a). Ten hours after cessation of growth (sample $A_{6}$ of Fig. I) almost all cells had abnormal mesosomes. In rare cases a large mesosome was found at an asymmetric position (Fig. $2 b$ ) or connected to a prespore septum (Fig. 2c).

If the same mutant was grown in NSMP plus malate or glutamate $(2 \mathrm{mg} / \mathrm{ml})$, the culture grew to a considerably higher $E_{600}$ and later lysed without producing heat-resistant spores; no prominent mesosomes could be seen.

Mutants 60846 and 60863 are deficient in both cytochrome $a$ and $c$. Both strains grew only to $E_{600} \mathrm{I} \cdot 3$ in NSMP medium and sporulated very poorly. In samples of either mutant 


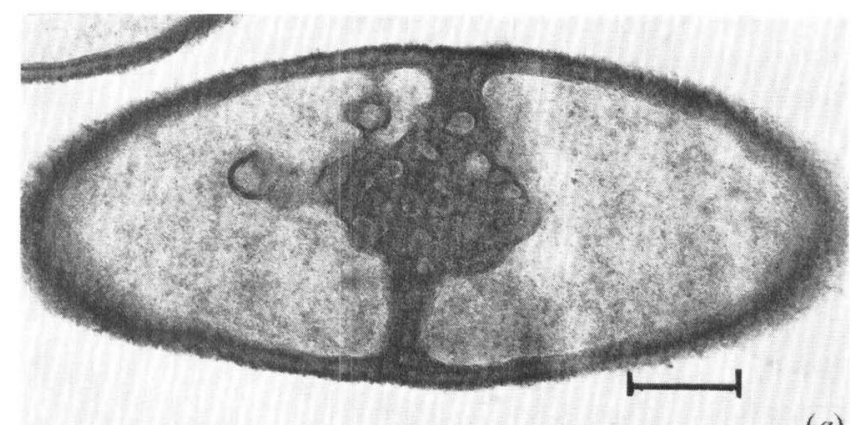

(a)

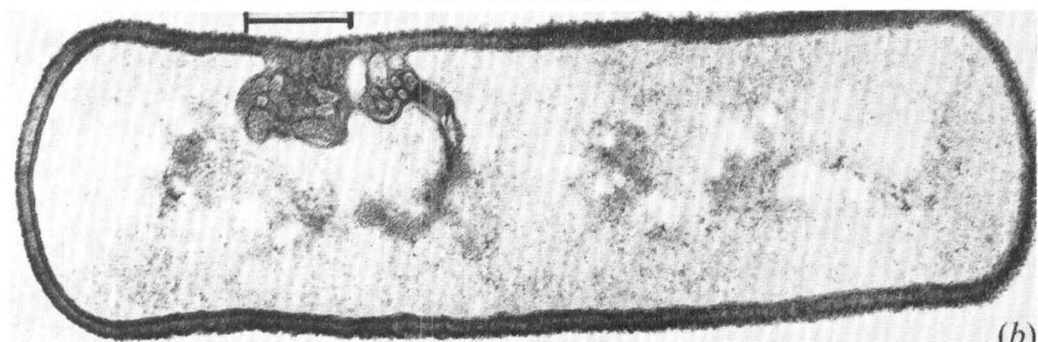

(b)
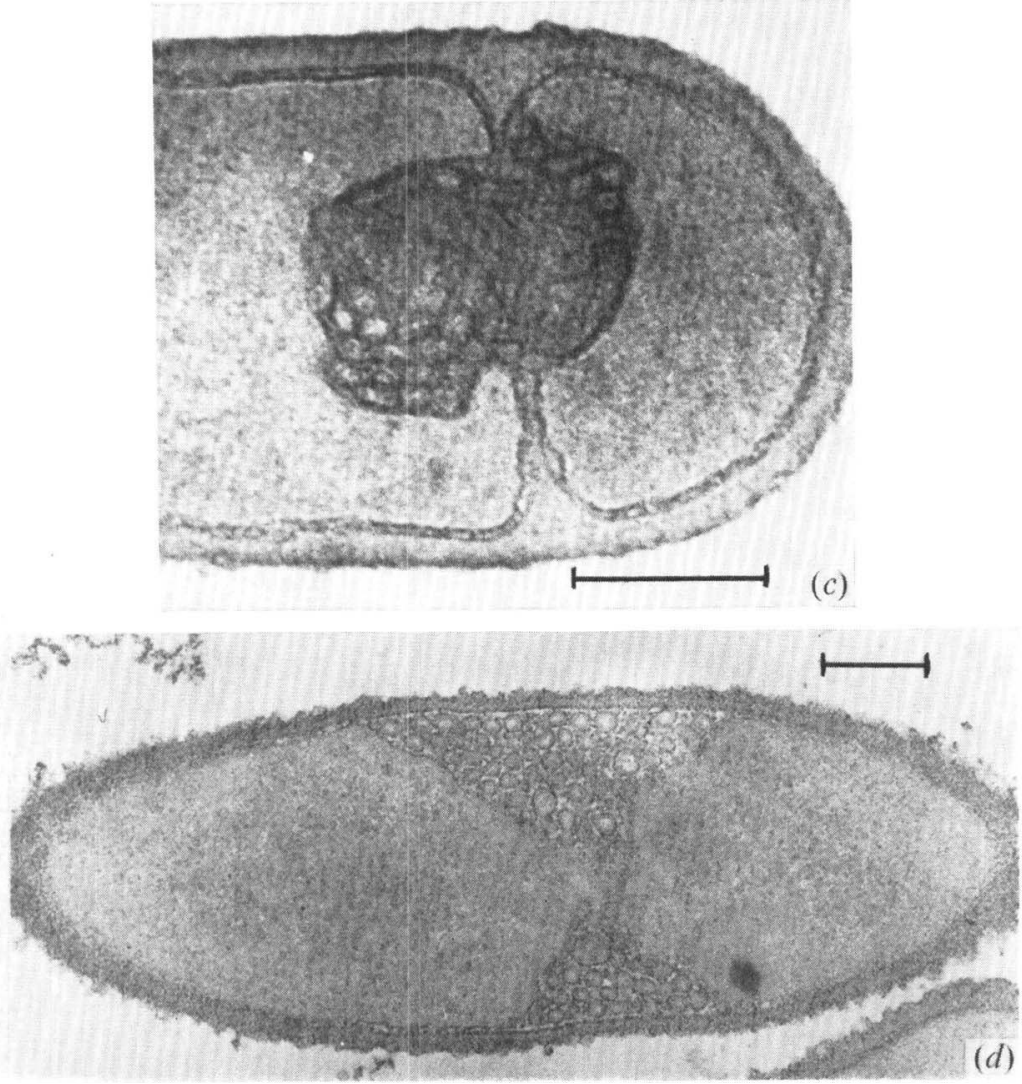

Fig. 2. Electron micrographs of ultrathin sections of cytochrome-deficient mutants. (a)-(c), Mutant 60843 at times $\mathrm{A}_{3}(a)$ and $\mathrm{A}_{6}(b, c)$ of Fig. I; $(d)$ mutant $608469 \mathrm{~h}$ after cessation of growth. The standard strain showed the usual development of forespores. Bars represent $0.2 \mu \mathrm{m}$. 
taken between 5 and $10 \mathrm{~h}$ after cessation of growth, gigantic vesicular mesosomes were observed at the cell division site (Fig. $2 d$ ) or occasionally the forespore septation site. In the presence of malate or glutamate $(2 \mathrm{mg} / \mathrm{ml})$ the cells grew to a higher $E_{600}$ and then became big and deformed and lysed without producing spores.

\section{REFERENCES}

Chapman, G. B. \& Hillier, J. (1953). Electron microscopy of ultrathin sections of bacteria. I. Cellular division in Bacillus cereus. Journal of Bacteriology 66, 362-373.

Ellar, D. J., Lundgren, D. G. \& Slepecky, R. A. (1967). Fine structure of Bacillus megaterium during synchronous growth. Journal of Bacteriology 94, $1189-1205$.

Fitz-JAMES, P. C. (1960). Participation of the cytoplasmic membrane in the growth and spore formation of Bacilli. Biophysical and Biochemical Cytology 8, 507-528.

Fitz-JAmes, P. C. \& Young, E. (1969). Morphology of sporulation. In The Bacterial Spore, pp. 39-72. Edited by G. W. Gould and A. Hurst. London and New York: Academic Press.

Fortnagel, P. \& Freese, E. (1968). Analysis of sporulation mutants. II. Mutants blocked in the citric acid cycle. Journal of Bacteriology 95, I43 I-I438.

Freese, E. B., Cole, R. M., Klofat, W. \& Freese, E. (1970). Growth, sporulation, and enzyme defects of glucosamine mutants of Bacillus subtilis. Journal of Bacteriology 1or, 1046-1062.

VAN ITERSON, W. (1965). Symposium on the fine structure and replication of bacteria and their parts. II. Bacterial cytoplasm. Bacteriological Reviews 29, 299-325.

Reaveley, D. A. \& Rogers, H. J. (1969). Some enzymatic activities and chemical properties of the mesosomes and cytoplasmic membranes of Bacillus licheniformis 6346. Biochemical Journal r13, 67-79.

ReusCh, V. M. \& BERGER, M. M. (I972). Membrane-bound enzymes in protoplast and mesosomal membranes. Federation Proceedings $3 \mathrm{I}$ (Abstract), 413.

RYTER, A. \& JACOB, F. (1963). Étude au microscope électronique des relations entre mésosomes et noyaux chez Bacillus subtilis. Compte rendu hebdomadaire des séances de l'Académie des sciences (Série D) 257, 3060-3063.

VAN DER WINKEL, E. \& MURRAY, R. G. E. (1962). Organelles intracytoplasmiques bactériens et site d'activité oxydo-réductrice. Journal of Ultrastructure Research 7, 185-199. 